We concluded that although the sickling test was not highly sensitive, it was more sensitive than solubility and the peripheral blood film method.

1. Okwi AL, Byarugaba W, Ndugwa CM, Parkes A, Ocaido M, Tumwine JK. Knowledge gaps, attitude and beliefs of the communities about sickle cell disease in eastern and western Uganda. East Afr Med J 2009;86(9):442-449.

2. Okwi AL, Byarugaba W, Ndugwa CM, Parkes A, Ocaido M, Tumwine JK. An update on the prevalence of sickle cell trait in Eastern and Western Uganda. BMC Blood Disorders 2010;10: 5doi:10.1186/1471-2326-10-5.

\section{Approval of chronic medication}

To the Editor: In response to Professor Rayner's letter to the SAMJ, ${ }^{1}$ I would like to point out that Discovery Health was able to resolve the case before it was published in your journal. Professor Rayner has indicated to us in writing that he would have withdrawn his letter to you, had it not been too late to do so.

Discovery Health formulates its funding policies using evidencebased medicine and in consultation with South Africa's various professional specialist societies and leadership. In the case of diabetes mellitus, current SEMDSA guidelines (published in 2009) do not recommend the use of $\mathrm{HbAlc}$ for diagnosis. We are aware of the American Diabetes Association statement referred to by Professor Rayner, which recommends the use of $\mathrm{HbAlc}$ as a diagnostic test. This continues to be debated in national forums, and in fact the most recent SEMDSA guidelines released in August 2010 reaffirm the position that HbAlc should not be used alone as a diagnostic criterion for diabetes or pre-diabetes.
We recognise that individual cases do sometimes merit exceptional decisions on clinical grounds. The doctors we employ, some of whom are referred to in Professor Rayner's letter, have the challenging task of applying our funding policies in a way that is fair and consistent, taking into account both the best interests of individual patients and our membership base as a whole. They do so with great care. In this specific case, we failed to recognise up front that a clinical exception could have been made. Going forward we will endeavour to further enhance this aspect of our service.

The sustainability of our members' medical scheme benefits depends on our ability to responsibly apply the principles of evidencebased medicine wherever possible. We will always actively engage with the health care profession and the various representative societies to ensure that our funding decisions are clinically sound, but as noted above, there are often complex cases in 'grey areas' and we acknowledge that we do and will make errors in some of these situations. We always try to correct these as quickly as possible, and we appreciate the feedback we receive, which assists in improving our overall approach. We call on all health care professionals to work with us in a spirit of co-operation, rather than conflict. Finding the balance between what is best for each patient and for our private health care system as a whole is a complex task, and needs an active partnership between responsible funders and practitioners.

\section{Jonathan Broomberg}

Chief Executive Officer, Discovery Health

jonathanb@discovery.co.za

1. Rayner B. Approval of chronic medication - Discovery Health hits new lows. S Afr Med J 2010;100:482. 